УДК [94 : 328.13] (44-054.52: 28) «2012/2017»

DOI: https://doi.org/10.33782/eminak2021.2(34).531

\title{
МІНІСТРИ-МУСУЛЬМАНИ У ФРАНЦУЗЬКИХ УРЯДАХ (2012-2017)
}

\author{
Богдана Сипко \\ Львівський національний університет імені Івана Франка (Львів, Україна) \\ e-mail: bogdanasypko@gmail.com \\ ORCID: https://orcid.org/0000-0002-3136-9340
}

У статті, на основі офіційного державного друкованого органу «Jоurnal officiel de la République Française», звітів Сенату та Національної Асамблеї, матеріалів виступів, інтерв'ю та мемуарів проаналізовано склади французьких урядів періоду президентства Ф. Олланда та простежено, яку роль у них відігравали мусульмани. З'ясовано, що концептуальною для Ф.Олланда була злагодженість уряду, тому більшість міністрівмусульман були членами Соціалістичної партії. Троє з чотирьох політиків народилися не у Франції, половина зберегла подвійне громадянство. Тому у риториці апелювали до культурного, релігійного й етнічного різноманіття Республіки, а питання історії, політики пам'яті, світськості, боротьби проти усіх форм дискримінації були ключовими.

Ключові слова: іслам, політики-мусульмани, уряд, Франсуа Олланд, Франція

У травні 2012 р. я планую створити команду, де досвід поєднувався б із прагненням оновлення.

Відтак, я формую уряд,

маючи на меті врівноважувати різноманітність і злагодженість. Франсуа Олланд, Уроки влади

На початку XXI ст. на території Французької республіки мешкала найбільша ісламська умма Заходу, яка нараховувала приблизно 5-6 млн. осіб. 3 огляду на зростаючу терористичну загрозу, восени 2020 р. чинний президент Еммануель Макрон закликав розрізняти «іслам» та «ісламізм», а також анонсував низку заходів, спрямованих на захист принципу світськості та боротьбу проти «ісламістського сепаратизму». Ці заяви викликали хвилю обурення в ісламському світі, зокрема у Туреччині, де заявили, що мусульмани Франції піддаються систематичній дискримінації та не мають можливостей для самореалізації. Відтак, актуальним $є$ аналіз стану представленості мусульман у вищих ешелонах французької влади.

В одній із нещодавніх статей Богдана Сипко констатувала1, що Ніколя Саркозі прагнув засвідчити сприяння ґендерній, етнічній і релігійній «різноманітності» влади, запрошуючи в уряди Франсуа Фійона жінок іммігрантського походження ісламського віросповідання. Обраний 2012 р. Президентом Республіки представник Соціалістичної партії Франції Франсуа Олланд прагнув протиставитися попереднику. На зміну режиму т. зв. «гіперпрезидентства»² (термін запропонований журналістами, як сарказм на маніпулювання Н. Саркозі 3МI) мало прийти «норма-

\footnotetext{
1 Сипко Б. Мусульмани в урядах Франсуа Фійона // Емінак: науковий щоквартальник. 2020. № 2(30). C. 209-219. DOI: https://doi.org/10.33782/eminak2020.2(30).421

2 Windisch J. Omniprésence de l'image - omniprésence du président: Les caricatures sur Nicolas Sarkozy (2007-2012). Wien: Universität Wien, 2014. P. 36.
} 
льне президентство»3. Метою пропонованої статті $є$ з'ясувати, чи відрізнялися підходи Франсуа Олланда (2012-2017) у формуванні урядів у контексті залучення до нього осіб ісламського віросповідання. Тим більше, що у мемуарах сьомого Президента П’ятої республіки питання кадрової політики окреслені доволі скупо: «Я шукав тридцятирічних обранців, щоб забезпечити оновлення, багатоманітність і паритет, які я обіцяв громадянам. Я певен, що таланти, які виходять на люди, у тому числі й у складні моменти п'ятиріччя, будуть перевагами для завтрашніх лівих сил. Для прикладу наведу такі постаті, як Наджат Валло Белькасем, Міріем ель Хомрі, Матіас Фекль, Еріка Барейтс або Еммануель Косс»4.

Закономірно, що це питання ще не знайшло належного висвітлення в історіографії. Зокрема, Орелін Кардозо 5 , Катрін Коломбе 6 та Сандрін Офре 7 у своїх студіях торкалися окремих аспектів діяльності політиків-мусульман, не акцентуючи на їхній релігійній приналежності, а Богдана Сипко у цьому контексті проаналізувала періоди президентства Жака Ширака та Ніколя Саркозі ${ }^{8}$. Тому джерельну базу статті становить архів офіційного друкованого органу Франції - Journal officiel de la République Française (далі - JORF) за 2012-2017 рр., звіти Сенату 9 та Національної Асамблеї10, мемуари Ф.Олланда ${ }^{11}$ стенограми виступів та інтерв'ю політиківмусульман, доступні на урядовій інтернет-платформі Vie-publique.fr.

У першому уряді Жана-Марка Айро (15 травня - 18 червня 2012) портфель міністра з прав жінок отримала Наджат Валло Белькасем, на неї ж поклали функції речниці. Делегованими міністрами стали Яміна Бенгігі (з питань французів за кордоном і Франкофонії) та Кадер Аріф (з питань ветеранів) ${ }^{12}$. Згідно французького за-

\footnotetext{
3 Олланд Ф. Уроки влади: мемуари [пер. з франц. Є. Марічева]. Харків: «Фоліо», 2019. С. 27.

${ }^{4}$ Ibid. C. 324.

5 Cardoso A. La superwoman est-elle antiféministe? Analyse des discours de la presse féminine sur l'articulation entre vie professionnelle et vie familiale // Recherches féministes. 2014. № 27 (1). P. 227. DOI: https://doi.org/10.7202/1025424ar

${ }^{6}$ Collombet $\mathrm{C}$. Histoire des congés parentaux en France. Une lente sortie du modèle de rémunération de la mère au foyer // Revue des politiques sociales et familiales. 2016. №¹22. P.121. DOI: https://doi.org/10.3406/caf.2016.3168
}

${ }^{7}$ Aufray S. Le site Mémoire des hommes et ses évolutions: entre mémoire et histoire // La Gazette des archives. 2014. №ㅇ2ㅇ. P. 75-76. DOI: https://doi.org/10.3406/gazar.2014.5164

${ }^{8}$ Сипко Б. Політичне життя французьких мусульман: віл участі у виборах до урядових посад (1995-2007) // Вісник Львівського університету. Серія історична. 2017. Спецвипуск. С. 745-760. DOI: http://dx.doi.org/10.30970/his.2017.0; Сипко Б. Мусульмани в урядах Франсуа... С. 209-219.

${ }^{9}$ Rapport d'information du Sénat № 757 fait au nom de la mission d'information sur l'organisation, la place et le financement de l'islam et de ses lieux du culte. Session extraordinaire 2015-2016. Paris: La documentation Française, 2016. 578 p.; Rapport du Sénat № 590 fait au nom de la commission d'enquête sur le fonctionnement du service public de l'éducation, sur la perte des repères républicains que révèle la vie dans les établissements scolaires et sur les difficultés rencontrées par les enseignants dans l'exercice de leur profession.. Tome 1. Session extraordinaire 2014-2015. Paris: La documentation Française, 2015. 241 p.; Rapport du Sénat № 590 fait au nom de la commission d'enquête sur le fonctionnement du service public de l'éducation, sur la perte des repères républicains que révèle la vie dans les établissements scolaires et sur les difficultés rencontrées par les enseignants dans l'exercice de leur profession. Tome 2. Session extraordinaire 2014-2015. Paris: La documentation Française, 2015. 605 p.

10 Rapport d'information fait au nom de la mission d'information sur les moyens de Daech. Tome 1. Rapporteur M. Kader Arif. Paris: Assemblée Nationale, 2016. 203 p.; Rapport d'information fait au nom de la mission d'information sur les moyens de Daech. Tome 2. Rapporteur M. Kader Arif. Paris: Assemblée Nationale, 2016. $537 \mathrm{p}$.

11 Олланд Ф. Уроки влади: мемуари...

12 Décret du 16 mai 2012 relatif à la composition du Gouvernement // Journal officiel de la République Française (JORF). 17 mai 2012. P. 9149. 
конодавства, після парламентських виборів обов'язково формується новий уряд. Тому у початковому складі другого кабінету Ж.-М.Айро (18 червня 2012 31 березня 2014) перелічені особи зберегли свої портфелі, але було уточнено назву мандату Яміни Бенгігі - «делегований міністр з питань Франкофонії»13. 31 березня 2014 р., у відповідь на поразку «лівих» на місцевих виборах, Ж.-М. Айро подав у відставку. Новий уряд сформував Мануель Вальс (31 березня - 26 серпня 2014). 2 квітня міністром з прав жінок, міста, молоді та спорту призначили Н. Валло Белькасем ${ }^{14} .9$ квітня кабінет доукомплектували, зокрема Кадер Аріф став «держсекретарем з питань ветеранів і політики пам'яті»15.

Внаслідок серпневої урядової кризи М. Вальс подав у відставку, але Ф. Олланд висловив йому довіру та доручив сформувати другий кабінет (25 серпня 2014 6 грудня 2016). 26 серпня престижний портфель міністра національної освіти, вищої освіти та науки отримала Н. Валло Белькасем, підтверджено повноваження Кадера Аріфа, а державним секретарем з питань політики міста стала Міріем ель Хомрі ${ }^{16} .21$ листопада 2014 р. «за власним бажанням» припинено повноваження Кадера Аріфа17, однак йшлося про непрозорі тендерні процедури, в яких брали участь його родичі18. 2 вересня 2014 р. Міріем ель Хомрі стала повноправним міністром з питань праці, працевлаштування, професійного розвитку та соціального діалогу19. Оскільки М. Вальс висловив побажання взяти участь у новій президентській кампанії, 6 грудня 2016 р. уряд, в якому Н. Валло Белькасем і М. ель Хомрі зберегли свої портфелі, сформував Бернар Казньов (6 грудня 2016 - 10 травня 2017) 20.

Наджат Валло Белькасем зуміла втриматися на урядових посадах упродовж усієї президентської каденції Франсуа Олланда, що й не дивно, враховуючи, що під час електоральних кампаній 2007 і 2012 років вона була речницею кандидатів від Соціалістичної партії. Друга у сім'ї з семи дітей, Наджат народилася у Марокко, 1982 р. у 5-річному віці за програмою об’єднання сімей переїхала до Франції, де їі батько працював на будівництві. У 1995 р., ставши повнолітньою, отримала французьке громадянство, але паралельно зберегла й марокканське 21 . Про своє походження Н. Валло Белькасем говорила: «Так, я дитя імміграції; так, я дитя об’єднання сім'ї; так, я не француженка за походженням»22. У престижному пари-

\footnotetext{
13 Décret du 21 juin 2012 relatif à la composition du Gouvernement // JORF. 22 juin 2012. P. 10288.

14 Décret du 2 avril 2014 relatif à la composition du Gouvernement // JORF. 3 avril 2014. P. 6388.

15 Décret du 9 avril 2014 relatif à la composition du Gouvernement // JORF. 10 avril 2014. P. 6560.

16 Décret du 26 août 2014 relatif à la composition du Gouvernement // JORF. 27 août 2014. P. 14385.

17 Décret du 21 novembre 2014 relatif à la composition du Gouvernement // JORF. 22 novembre 2014.

P. 19569.

${ }^{18}$ Kader Arif, un fidèle à la porte // Libération. 21 novembre 2014 [En ligne]. URL: https://www.liberation.fr/france/2014/11/21/kader-arif-un-fidele-a-la-porte_1148188

${ }^{19}$ Arrêté du 2 septembre 2015 portant nomination au cabinet de la ministre de travail, de l'emploi, de la formation professionnelle et du dialogue social // JORF. 30 septembre 2015. P. 17445.

20 Décret du 6 décembre 2016 relatif à la composition du Gouvernement // JORF. 6 décembre 2016.

21 Подвійне, а то й множинне, громадянство у Франції дозволене, навіть глава уряду Мануель Вальс був і підданим Іспанії, а сенаторка Естер Бенбасса мала їх аж три - французьке, турецьке та ізраїльське.

22 Interview de Mme Najat Vallaud-Belkacem, ministre de l'éducation nationale, de l'enseignement supérieur et de la recherche à Europe 1 le 25 août 2016, sur l'islam, le racisme et sur les arrêtés municipaux anti burkinis [En ligne]. URL: https://www.vie-publique.fr/discours/200499-interview-de-mme-najatvallaud-belkacem-ministre-de-leducation-nationa
} 
зькому навчальному закладі Сьянс По Наджат познайомилася із майбутнім чоловіком Борисом Валло, істориком за фахом. На нашу думку, саме цей фрагмент біографії вплине на прискіпливу увагу майбутнього міністра освіти до місії та методики викладання історії. У 2002 р. юрист і адвокат розпочала політичну кар'єру в лавах Соціалістичної партії. Успішно зарекомендувавши себе на місцевому рівні в Ліоні, 2007 р. журнал Lyon Capitale навіть назвав її «Ліонкою року», 2012 р. вийшла на загальнонаціональну політичну арену.

Із січня 2012 р. Н. Валло Белькасем лобіювала Закон про рівність чоловіків і жінок, прийнятий Національною Асамблеєю і Сенатом 23 липня 2014 р.23 Тому закономірно, що ставши Президентом, Ф. Олланд доручив колишній речниці саме міністерство з прав жінок. На цьому посту Наджат послідовно відстоювала інтереси жінок, апелюючи до різних форм дискримінації, від яких вони потерпають. У листопаді 2012 р. Валло Белькасем звертається до такої болючої теми, як жіноче обрізання. Міністр наголосила на тому, що щойно з 1983 р. таке калічення є кримінальним злочином у Франції, але з об’єктивних причин точних статистичних даних бути не може. Показово, що речниця уряду підкреслила, що «не можна в цих питаннях вказувати пальцем на ту чи іншу релігію, бо явище передувало появі монотеїзму. Жоден релігійний текст його не виправдовує» 24 . Таке уточнення пов'язане з тим, що засоби масової інформації часто ідентифікували традицію жіночого обрізання саме з культурою ісламу.

Через рік міністр гостро засудила проституцію, наголошуючи на тому, що жінок до неї часто змушують: «Якщо хтось може купити, значить хтось мусить продатися, і зазвичай не добровільно» 25 . Н. Валло Белькасем підкреслює, що «купують» насамперед жіноче тіло, бо це «усталена практика». На їі думку, у боротьбі проти проституції коректно використовувати термін «аболіціонізм», оскільки йдеться про сексуальне рабство, в якому перебувають жінки.

Окрім боротьби з такими маргінальними практиками як обрізання та проституція, Наджат Валло Белькасем намагалася, за ії ж словами, зробити так, щоб «рівність між чоловіками та жінками, яка існує на папері, стала реальною» 26. У цьому контексті надзвичайно важливим було створення рівних умов для професійного розвитку жінки. У жодному випадку, на її думку, не можна заборонити добровільне переривання вагітності, також необхідно провести реформу відпустки по догляду за дитиною. До 6 місяців, які гарантувалися до 2014 р., міністр запропонувала додати ще пів року, якщо їх візьме батько, а жінка зможе вийти на роботу. Для цього ж у 2014 р. профінансовано 100 тис. додаткових місць в яслах, на що виділено по-

\footnotetext{
${ }^{23}$ Qui sont les ministres du gouvernement Valls II? // Libération. 26 août 2014 [En ligne]. URL: https://www.liberation.fr/france/2014/08/26/le-gouvernement-valls-ii-a-la-loupe_1087471

24 Déclaration de Mme Najat Vallaud-Belkacem, ministre des droits des femmes, porte-parole du gouvernement, sur les mutilations sexuelles féminines et les mariages forcés, Paris le 27 novembre 2012 [En ligne]. URL: https://www.vie-publique.fr/discours/186589-declaration-de-mme-najat-vallaudbelkacem-ministre-des-droits-des-femme

25 Déclaration de Mme Najat Vallaud-Belkacem, ministre des droits des femmes, porte-parole du gouvernement, sur la lutte contre la prostitution et les réseaux du proxénétisme, Paris le 29 novembre 2013 [En ligne]. URL: https://www.vie-publique.fr/discours/189708-declaration-de-mme-najat-vallaudbelkacem-ministre-des-droits-des-femme

26 Déclaration de Mme Najat Vallaud-Belkacem, ministre des droits des femmes, porte-parole du gouvernement, sur l'égalité entre les femmes et les hommes, Paris le 20 janvier 2014 [En ligne]. URL: https://www.vie-publique.fr/discours/190244-declaration-de-mme-najat-vallaud-belkacem-ministredes-droits-des-femme
} 
над 1 млрд. євро. Міністр закликала не лише боротися із насильством у сім'ях, залучивши до цього профільних фахівців у медичній галузі, соціальних працівників, поліцейських, адвокатів, а й «врятувати» жінок від додаткової неоплачуваної роботи вдома. Кредо для Н. Валло Белькасем була поява «жінок активних, автономних, емансипованих, освічених і дипломованих, які беруть участь в економічному та соціальному житті країни, жінок, які досягають успіху» 27 . На нашу думку, така позиція міністра мала, передусім, суб'єктивні причини - донька багатодітного марокканського робітника завдяки власній старанності та наполегливості змогла піднятися на вершину суспільної ієрархії Франції, і тепер прагнула допомогти «звільнитися» іншим жінкам.

2 квітня 2014 р. сферу компетенції Валло Белькасем розширили, відтоді вона мала опікуватися ще й питаннями міста, молоді та спорту. Закономірно, що її увагу привернули насамперед «пріоритетні квартали» (до 2012 р. - «складні міські зони») ${ }^{28}$. Справжньою допомогою з безробіття у цих кварталах, на їі думку, стали б не виплати, а розширення транспортної мережі, яка подолала б ізольованість від ринку праці, а також позики для створення малого бізнесу вихідцями з цих територій ${ }^{29}$.

26 серпня 2014 р. Наджат Валло Белькасем стала не лише першою особою з подвійним громадянством на посаді міністра освіти, а й першою жінкою на цьому посту у Франції. Упродовж наступних трьох років міністр намагалася оновити систему освіти, насамперед середньої. У цьому ключі детермінантами для неї були визначальна роль історії та принципу світськості у формуванні нових громадян. Ще в жовтні 2014 р. Наджат заявила, що належить до людей, які захоплюються історією, оскільки саме ця наука допомагає зрозуміти сьогодення. Валло Белькасем виокремила три постаті, які найбільше вплинули на формування ії світогляду Ніколя Кондорсе, Олімп де Гуж і Нельсон Мандела, оскільки вони зуміли порушити усталений суспільний лад і цим забезпечили подальший його розвиток. Міністр виокремила три першочергові завдання для свого відомства: по-перше, передати кожному учневі спільний стержень знань, компетентностей і культури, по-друге, боротися з нерівністю і детермінізмом, i, по-третє, працювати над тим, щоб школа стала відкритою до світу (насамперед, працедавців) ${ }^{30}$.

Показово, щодо терактів 2015 р. міністр апелювала до того, що світськість, «не просто шкільний принцип, а хребет Школи» 31 не може бути дискримінаційною. У

\footnotetext{
27 Ibidem.

28 Детальніше про ці територіальні одиниці див.: Сипко Б. Етно-соціальні проблеми французьких передмість на зламі XX-XXI ст. // Wspołczesne wyzwania bezpieczeństwa Europejskiego. Kraków: Wydawnictwo Attyka, 2016. S. 203-217.

29 Interview de Mme Najat Vallaud-Belkacem, ministre des droits des femmes, de la ville, de la jeunesse et des sports à France 2 le 17 juin 2014 sur la politique de la ville et notamment la «carte de la pauvreté» [En ligne]. URL: https://www.vie-publique.fr/discours/191446-interview-de-mme-najat-vallaudbelkacem-ministre-des-droits-des-femmes

30 Discours de Mme Najat Vallaud-Belkacem, ministre de l'éducation nationale, de l'enseignement supérieur et de la recherche sur la place des l'histoire et l'idéologie, Blois le 10 octobre 2014 [En ligne]. URL: https://www.vie-publique.fr/discours/192686-declaration-de-mme-najat-vallaud-belkacem-ministrede-leducation-natio

31 Déclaration de Mme Najat Vallaud-Belkacem, ministre de l'éducation nationale, de l'enseignement supérieur et de la recherche sur l'anniversaire de la séparation de l'Eglise et de l'Etat, Paris le 9 décembre 2014 [En ligne]. URL: https://www.vie-publique.fr/discours/193190-declaration-de-mmenajat-vallaud-belkacem-ministre-de-leducation-natio
} 
тому числі світськість не може вдягати маски ісламофобії: «Релігійна свобода - це свобода вираження свідомості. Світськість не $\epsilon$ інструментом переслідування релігійності, а можливістю забезпечити гармонійне та плюралістичне співжиття» 32 . Однак, у січні-листопаді 2015 р. її риторика змінює акценти: «Республіка не визнає, і ніколи не визнає учнів мусульман, євреїв, християн чи атеїстів; вона визнає лише громадян, і щоб стати такими ми повинні мобілізуватися в єдності, аби досягти успіху та передати любов до нашої Батьківщини, любов до нашої історії і наших цінностей»33. Таке переосмислення, на нашу думку, пов'язане не з самими терактами, ініційованими ІДІЛ, а радикалізацією старшокласників, яка проявилася, у тому числі, й у зриві хвилини мовчання за жертвами терактів. Оскільки у першому випадку йшлося про зовнішню загрозу, а в другому тріщину отримав сам фундамент - система освіти. Так, у січні 2015 р. під час хвилини мовчання у пам'ять про жертв терактів, у редакції тижневика Charlie Hebdo у школах зафіксовано 200 порушень. Тому в листопаді 2015 р. напередодні нової траурної церемонії міністерство опублікувало 7-сторінковий порадник для вчителів з проведення хвилини мовчання ${ }^{34}$.

Під егідою Наджат Валло Белькасем розпочалася кампанія боротьби проти радикалізації учнів середньої школи, покликана не лише попереджати цей феномен у соціо-виховній діяльності, а й виправляти промахи. Міністерство розробило спеціальний посібник для вчителів, в якому проаналізовані маркери радикалізації учнів і наведена процедура подальших дій 35 . У цьому ж ключі варто розглядати сенс нового Морального та громадянського виховання, запровадженого 3 2015/2016 н. р. Передбачалося, що кожен учень відвідає 300 таких уроків. У квітнітравні 2015 р. підготували директорів, інспекторів і референтів, які до кінця року мали перекваліфікувати 300 тис. вчителів ${ }^{36}$.

Ініціативи міністра не обмежилися державною освітою. Ще 31 грудня 1959 р. Закон Мішеля Дебре запропонував приватним навчальним закладам державні дотації, якщо вони укладуть контракт із державою. Для цього навчальний заклад мав мінімум п'ять років існувати без контракту, освітній рівень вчителів повинен відповідати державним вимогам, а релігійні уроки мали стати факультативними 37. Школи, які підписали контракт, підлягали частим перевіркам. Одразу після підпи-

\footnotetext{
32 Déclaration de Mme Najat Vallaud-Belkacem, ministre de l'éducation nationale, de l'enseignement supérieur et de la recherche sur la laïcité et la liberté religieuse à l'école, Paris le 21 octobre 2014 [En ligne]. URL: https://www.vie-publique.fr/discours/192693-declaration-de-mme-najat-vallaudbelkacem-ministre-de-leducation-natio

33 Déclaration de Mme Najat Vallaud-Belkacem, ministre de l'éducation nationale, de l'enseignement supérieur et de la recherche sur la citoyenneté et la laïcité, Paris le 12 mai 2015 [En ligne]. URL: https://www.vie-publique.fr/discours/195188-declaration-de-mme-najat-vallaud-belkacem-ministrede-leducation-natio

34 Interview de Mme Najat Vallaud-Belkacem, ministre de l'éducation nationale, de l'enseignement supérieur et de la recherche à France-Inter le 16 novembre 2015 sur les suites aux attentats terroristes du 13 novembre à Paris [En ligne]. URL: https://www.vie-publique.fr/discours/197277-interview-demme-najat-vallaud-belkacem-ministre-de-leducation-nationa

35 Déclaration de Mme Najat Vallaud-Belkacem, ministre de l'éducation nationale, de l'enseignement supérieur et de la recherche sur la prévention de la radicalisation, Paris le 12 novembre 2015 [En ligne]. URL: https://www.vie-publique.fr/discours/198121-declaration-de-mme-najat-vallaud-belkacemministre-de-leducation-natio

${ }^{36}$ Rapport du Sénat № 590.T. 2. 409.

37 Rapport d'information du Sénat № 757. 106.
} 
сання держава починала виплачувати зарплати вчителям, контролювати навчальні програми, календар і принцип свободи совісті, комуна мала утримувати шкільні приміщення, оплачувати транспортні витрати, що істотно здешевлювало роботу школи та робило її привабливішою для батьків, яким потрібно було лише здійснювати інвестиційні внески на духовний розвиток учнів. Тому не дивно, що до початку XXI ст. 98\% приватних шкіл підписали контракт із державою.

Але 2\% шкіл залишалися поза цією системою (понад 1 тис., у т. ч. 300 конфесійних - 200 католицьких і майже 50 мусульманських). Для того, аби створити навчальний заклад без контракту, необхідно було подати досьє мерові комуни, ректорові навчального округу, префектові, а тоді прокуророві Республіки. Надані документи мали засвідчити, що заявник може забезпечити навчальний процес, відповідно до чинних вимог (наявність приміщення, освітній рівень вчителів). Весь контроль навчального процесу у таких навчальних закладах здійснювало керівництво школи, відповідно, релігійне виховання могло бути обов'язковим предметом, державні перевірки були лише через рік після створення школи. Міністр вирішила, що така ситуація незадовільна та 6 квітня 2016 р. запропонувала замінити режим декларацій під час створення приватних навчальних закладів без контракту на систему попередніх дозволів ${ }^{38}$. Однак, навіть після посилення інспекцій (у 2015/2016н. p. перевірили 14\% навчальних закладів без контракту) не помітили у них радикалізації, натомість зафіксували нижчий рівень викладів загальних предметів і відтворювальні методики навчання).

Окрім Морального та громадянського виховання місію запобігання радикалізації та формування критичного мислення Валло Белькасем покладала на історію. Показово, що до фундаментальних знань вона відносила вміння читати, писати, рахувати та орієнтуватися в історії Франції. Для цього у початковій школі виділяли 2,5 години на тиждень, у коледжі - три, ліцеї - 3,5 години. Що ж стосується того, що саме необхідно викладати, то основний акцент робили на Франції, історію інших країн подавали лише в контексті впливів і взаємовпливів із Республікою. Адже важливою була саме ідеологічна складова: «Сучасні учні мають прекрасний доступ до інформації, насамперед завдяки Інтернету. Але бракує її критичного аналізу. Саме історичні освіта має навчити їх відрізняти правду та фальсифікації, критично мислити» 39.

Однак, попри всі докладені зусилля, ініціативи Наджат Валло Белькасем із дерадикалізації не увінчалися успіхом, свідченням чого у далекосяжній перспективі стало обезголовлення при виході з ліцею у жовтні 2020 р. 18-річним чеченським біженцем вчителя історії Самуеля Паті, який аналізував на уроці карикатури на Пророка Моххамеда. Що й не дивно, з огляду на те, що 2015-2017 рр. - це період найвищого піднесення псевдодержавного терористичного утворення ІДІЛ, яке одним із ключових ворогів обрало Францію, як уособлення світськості. Народженій у мусульманській сім'ї, феміністці за переконаннями, на посаді міністра захисту прав жінок, згодом освіти, Валло Белькасем довелося маневрувати, оскільки вона мусила поєднати захист основоположного принципу світськості, забезпечити реальну

\footnotetext{
38 Ibid. 104.

39 Déclaration de Mme Najat Vallaud-Belkacem, ministre de l'éducation nationale, de l'enseignement supérieur et de la recherche sur l'enseignement de l'histoire, Paris le 3 juin 2015 [En ligne]. URL: https://www.vie-publique.fr/discours/195196-declaration-de-mme-najat-vallaud-belkacem-ministrede-leducation-natio
} 
рівність чоловіків і жінок і при цьому наголошувати на універсальних цінностях ісламу. У цьому Наджат допомогла позиція Президента Республіки, який вважав і неодноразово наголошував, що не можна ототожнювати іслам та ісламізм ${ }^{40}$. Найпоказовішим у контексті пошуку консенсусу між цими детермінантами, на нашу думку, є інтерв’ю від 26 серпня 2016 р. в якому Валло Белькасем пояснює свою позицію щодо буркіні (після теракту у Ніцці муніципалітети низки південнофранцузьких міст заборонили жінкам з'являтися на пляжах у цьому типі купальних костюмів): «Особисто я - проти буркіні, думаю, всім відомі мої феміністичні погляди [...] Поліція замість того, щоби ганяти жінок у буркіні з пляжу, краще б охороняла школи [...] Не можна обмежувати нерівноправність чоловіків/жінок лише однією релігією - ісламом. Ультраправих чомусь не чути, коли говорять про подружнє насильство чи нижчі зарплати жінок, а от про мусульманок...»41.

Пієтет до історії поділяв і Кадер Аріф, який початково опікувався справами ветеранів, а з 9 квітня 2014 р. і політикою пам'яті. Чому саме делегованому міністру з питань ветеранів доручили цю ділянку? Міністерство оборони було другим за потужністю культурним оператором держави (273 національні некрополі, більше 2 тис. військових дільниць на комунальних кладовищах, 9 потужних місць національної пам'яті, три національні музеї, які в 2013 р. відвідало 2 млн. осіб) ${ }^{42}$, а нагальною потребою став розвиток туризму місць пам'яті.

Близький соратник Франсуа Олланда, народився 1959 р. в Алжирі. Під час Другої світової війни його батько брав участь в Італійській кампанії, а в роки Алжирської війни був харкі (воював у складі допоміжних частин на боці Франції)43, а тому після укладення Евіанських угод мусів із сім'єю тікати на територію Республіки. Як і в більшості харкі, перші роки на території Франції були матеріально складними та пройшли у просторовій ізоляції від загалу суспільства. Але Кадер Аріф був вдячний за ті блага, які отримав від держави: «Дитя Алжиру, син Французької Республіки. Моє асоціювання з Францією відбулося через вивчення французької мови, якої батьки не знали, республіканську школу та військову службу»44. Політичну кар'єру розпочав у Тулузі, 2000 р. увійшов у Національне бюро соціалістичної партії. У 2004-2012 рр. був депутатом Європейського парламенту, щоб увійти до складу уряду, склав мандат.

Левова частка ініціатив К. Аріфа стосувалася вшанування харкі та інших військових із колишніх французьких колоній, що пов'язано з тим, що ці питання через батька мали для нього й особистісний вимір. Приступивши до виконання повноважень, делегований міністр ініціював створення інтернет-сайту про минуле харкі

\footnotetext{
40 Олланд Ф. Уроки влади... С. 132.

41 Interview de Mme Najat Vallaud-Belkacem, ministre de l'éducation nationale, de l'enseignement supérieur et de la recherche à Europe 1 le 25 août 2016 sur l'islam, le racisme et sur les arrêtés municipales anti burkinis [En ligne]. URL: https://www.vie-publique.fr/discours/200499-interview-de-mme-najatvallaud-belkacem-ministre-de-leducation-nationa

42 Déclaration de M. Kader Arif, ministre des anciens combattants sur le tourisme de mémoire, à Paris le 20 mars 2014 [En ligne]. URL: https://www.vie-publique.fr/discours/190742-declaration-de-m-kaderarif-ministre-des-anciens-combattants-sur-le-t

43 Детальніше про харкі див.: Сипко Б. От «забытых историей» до субъектов общественных отношений: проблема харки в годы президентской каденции Жака Ширака // Społeczeństwo i Polityka. Pismo edukacyjne. 2013. № 3 (36). S. 229-239.

${ }^{44}$ Déclaration de M. Kader Arif, secrétaire d'Etat aux anciens combattants et à la mémoire en hommage aux anciens combattants d'origine étrangère, à Paris le 21 mai 2014 [En ligne]. URL: https://www.viepublique.fr/discours/191222-declaration-de-m-kader-arif-secretaire-detat-aux-anciens-combattants
} 
на основі історичних документів. I 2013 р. завдяки Еріку Люка запрацювала сторінка Chemins de mémoire harkis (Стежки пам'яті харкі). 25 вересня 2013 р. у День вшанування харкі (запроваджений Жаком Шираком 2001р.) міністр підкреслив, що ця дата символізує зустріч із маловідомою, забутою, болючою і дуже часто зневаженою історією. На його думку, харкі - це честь і гордість Нації, але «видерті 3 рідної країни, згодом покинуті Францією, до якої вони залишалися лояльними та вірними [...] Спочатку закриті у тимчасових таборах, згодом відокремлені в історії»45. I саме лакуна в історії, на його думку, була найбільш загрозливою. А вирішувати ситуацію можна було шляхом перегляду шкільної програми. Через рік презентував план дій, покликаний відновити пам'ять про харкі у Республіці через визнання помилок, яких допустилася Франція 46 , але його реалізації перешкодила передчасна відставка. У численних виступах Кадер Аріф підкреслював значення вихідців із Північної Африки та Сенегальських стрільців у французьких перемогах, зокрема: «Армія Вільної Франції, очолювана де Голлем, зародилася в колоніях і складалася в основному з африканських солдатів» ${ }^{47}$. Найбільший пієтет викликали саме магрибські солдати, тим паче, що «Середземне море - це не кордон, це міст між Францією та Магрибом»48.

Ключовим у контексті політики пам'яті був 2014 рік, оскільки - це 100-річчя Великої війни, 70-річчя звільнення Франції від нацистів, 60-річчя завершення війни в Індокитаї. Показово, що Кадер Аріф зробив акцент на військових із французьких колоній: «Франція віддасть шану бійцям різного походження, які билися чи померли за неї, а також передасть молодим поколінням пам'ять, яка є основоположною для громадянства і політики співжиття»49. Вшановуючи полеглих у Верденській м'ясорубці, делегований міністр назвав Верден - «землею солідарності між народами»50, маючи на увазі, насамперед французів, німців, американців, австрійців, поляків, італійців, румунів, алжирців, марокканців, сенегальців. Цікавим $\epsilon$ визначення патріотизму, яке дає К. Аріф: «Бути патріотом - це захищати цінності, які $\epsilon$ цементом нашої Нації; і битися проти загроз всередині і назовні»51. А націона-

\footnotetext{
45 Déclaration de M. Kader Arif, secrétaire d'Etat aux anciens combattants sur les efforts en faveur des harkis, à Paris le 25 septembre 2013 [En ligne]. URL: https://www.vie-publique.fr/discours/189091declaration-de-m-kader-arif-ministre-des-anciens-combattants-sur-les

46 Message de M. Kader Arif, secrétaire d'Etat aux anciens combattants et à la mémoire, à l'occasion de la Journée nationale d'hommage aux harkis et autres membres des formations supplétives, le 25 septembre 2014 [En ligne]. URL: https://www.vie-publique.fr/discours/192461-message-de-m-kader-arifsecretaire-detat-aux-anciens-combattants-et

47 Déclaration de M. Kader Arif, ministre des anciens combattants, en hommage aux Tirailleurs dits «Sénégalais», à la Teste de Buch le 23 août 2013 [En ligne]. URL: https://www.viepublique.fr/discours/188829-declaration-de-m-kader-arif-ministre-des-anciens-combattants-en-homma 48 Déclaration de M. Kader Arif, ministre des anciens combattants, en hommage aux anciens combattants algériens de l'armée française, à Alger le 23 février 2014 [En ligne]. URL: https://www.viepublique.fr/discours/190547-declaration-de-m-kader-arif-ministre-des-anciens-combattants-en-homma 49 Kader Arif. Conseil des ministres du 28 mai 2014. Les cycles commémoratifs de l'année 2014 [En ligne]. URL: https://www.vie-publique.fr/discours/191251-conseil-des-ministres-du-28-mai-2014-lescycles-commemoratifs-de-lanne

50 Déclaration de M. Kader Arif, ministre des anciens combattants sur le memoire de Verdun, à Paris le 20 février 2014 [En ligne]. URL: https://www.vie-publique.fr/discours/190531-declaration-de-mkader-arif-ministre-des-anciens-combattants-sur-le-m

51 Déclaration de M. Kader Arif, ministre des anciens combattants sur la Résistance en Corse, à Ajaccio le 9 septembre 2013 [En ligne]. URL: https://www.vie-publique.fr/discours/188966-declaration-de-mkader-arif-ministre-des-anciens-combattants-sur-le-7
} 
льна пам'ять має стати тим розчином, який об'єднає всіх співгромадян, незалежно від того, де народилися вони чи їхні батьки ${ }^{52}$.

Проте, Кадер Аріф так і не завершив ювілейний 2014 р. на посаді, оскільки 21 листопада подав у відставку через судове розслідування участі своїх близьких у непрозорих тендерних процедурах. Згодом звинувачення не підтвердилися, але в уряд Аріф так і не повернувся. 2014-2017 рр. він представляв Верхню Гарону у Національній Асамблеї, і навіть підготував два грунтовні інформаційні звіти про ІДІЛ53. Припускаємо, що депутати доручили цю справу К. Аріфу, насамперед, через його обізнаність із культурою ісламу. Лейтмотивом звітів $€$ те, що ІДІЛ, як уособлення терору та варварства, немає нічого спільного з ісламом і практикуючими мусульманами. Вслід за мусульманським світом доповідач відмовляється використовувати самоназву псевдодержавного утворення «Ісламська держава Іраку та Леванту», натомість використовує пежоративну абревіатуру Daech - «те, що дисонує».

Судове переслідування завершило й політичну кар'єру Яміни Бенгіґі, яка називала себе «першою жінкою-режисером магрибського походження». Вона народилась 1957 р. у Ліллі в сім'ї алжирських робітників, у 18 років була змушена покинути рідний дім, оскільки батько не схвалював її рішення стати режисером ${ }^{54}$. Вибір професії Я. Бенгігі (дівоче прізвище - Белаїді) пояснила прагненням «вписати батьків [іммігрантів першого покоління - Aвm.] в історію»: «Франція не визнала нас [іммігрантів - Aвm.] і про нас не говорила; країни, з яких ми приїхали, про нас не говорили і нічого про нас не знали; а наші батьки мовчали і нічого нам не розповідали... Як донька іммігрантів я хотіла вловити цю пам'ять і попрацювати з нею». Закономірно, що Яміна розпочала кар'єру в царині документального кіно, а стрічки «Ісламська жінка» (1994 р.), «Пам'ять іммігрантів» (1997 р.) і «Без історії!» (2000 р.) принесли їй визнання та золото Фестивалю документального кіно у Франції (1998 р.). Уже 2001 р. Я. Бенгігі успішно дебютувала у художньому кіно 55.

32008 р. паралельно із режисерською кар'єрою Бенгігі робить перші кроки у царині політики, ставши радницею з питань прав людини та боротьби проти дискримінації мера Парижа Бертрана Деланое. На відміну від К. Аріфа, який превентивно відмовився від мандата євродепутата, Я. Бенгігі залишила мерію Парижа щойно у червні 2012 р., впродовж місяця порушуючи закон перебуванням на двох посадах. Яміна щиросердо зізнавалася, що надзвичайно радіє новому призначенню, оскільки бачить широке поле для діяльності: «Так, я дуже горда бути міністром. Як, можливо, ви знаєте я сценаристка та режисерка художніх і документальних фільмів [...] Я створювала документальні фільми про імміграцію [...] Коли Президент Олланд попросив мене стати міністром Франкофонії, я зрозуміла, що є зв'язок із тим, що я робила стільки років [...] Сподіваюся залишити слід у цьому міністерс-

\footnotetext{
52 Déclaration de M. Kader Arif, ministre des anciens combattants sur la politique mémorielle, au Sénat le 4 février 2014 [En ligne]. URL: https://www.vie-publique.fr/discours/190510-declaration-de-m-kaderarif-ministre-des-anciens-combattants-sur-la-p

53 Rapport d'information fait au nom de la mission d'information sur les moyens de Daech. Tome 1. Rapporteur M. Kader Arif. Paris: Assemblée Nationale, 2016. 203 p.; Rapport d'information fait au nom de la mission d'information sur les moyens de Daech. Tome 2. Rapporteur M. Kader Arif. Paris: Assemblée Nationale, 2016. $537 \mathrm{p}$.

54 Fleuri B. Mémoires d'immigrés. L'heritage maghrébin de Yamina Benguigui. De l'ethos biographique aux hors sujets de la réception / B. Fleuri // Revues-analyses. 2008. Vol. 3. № 3. P. 109.

55 Сипко Б. Мусульманська спільнота у житті Французької Республіки (1995-2007): монографія. Львів: ЛНУ імені Івана Франка, 2017. С. 171-172.
} 
тві»56. Перевагою для цієї посади мадам Бенгігі вважала й своє алжирське походження: «Скажімо так, я вмію бути алжиркою у потрібні моменти. Так, я дуже близька до Алжиру [...] Я можу передавати повідомлення через свою франкоалжирську ідентичність»57. Пояснення виглядає дещо наївним, проте й заявами Яміна не обмежилася, сформувавши під своїм началом команду з осіб, які народилися у Франції, але зберегли алжирську ідентичність ${ }^{58}$. Схожі ініціативи 2015 р. pеалізує у міністерстві праці Міріем ель Хомрі щодо працівників марокканського походження ${ }^{59}$.

Пильну увагу Яміна Бенгігі приділила пропагуванню французької мови у світі. На її думку, французька мова вже давно позбулася рудиментів колоніалізму, і на початку XXI ст. є мовою солідарності та рівності, засобом стабільності та співжиття, толерантності та розмаїття, а також перманентної еволюції60. Стрімке зростання населення Африки створювало хороші перспективи для поширення Франкофонії. Але для того, щоб демографічна подія супроводжувалася передачею французької мови наступним поколінням, французький уряд повинен проводити виважену лінгвістичну політику. Французька мова мусить утвердитися в Африці як мова політики, економіки та культури. А для цього, насамперед, необхідно забезпечити високий рівень викладання французької мови за кордоном. Тому на 20 березня 2014 р. Яміна анонсувала програму «100 тис. викладачів для французької мови для Африки», створено спеціальну соціальну мережу для викладачів Vizamonde.

Делегований міністр не обмежилася африканським регіоном, справедливо вважаючи, що Азія у цьому контексті теж надзвичайно перспективна. У грудні 2012 р. вона побувала у Китайській народній республіці, з якою підписала угоду про присудження дипломів DELF/DALF китайцям61. Не менш важливою була підтримка за кордоном шкіл, які викладали предмети французькою мовою. Для цього створили бренд FrancEducation, який допомагав ідентифікувати та популяризувати іноземні шкільні заклади, які пропонували якісні франкомовні уроки. Станом на листопад 2012 р. його присвоїли 25 школам, а делегований міністр хотіла досягти цифри 50 у 2013 p. i 100 у 2015 p. 62.

\footnotetext{
56 Déclaration de Mme Yamina Benguigui, ministre de la francophonie, sur la Francophonie et sur l'immigration, à Dakar le 14 septembre 2012 [En ligne]. URL: https://www.viepublique.fr/discours/185919-declaration-de-mme-yamina-benguigui-ministre-de-la-francophonie-sur-la ${ }^{57}$ Entretien de Mme Yamina Benguigui, ministre de la francophonie, avec RFI le 23 janvier 2014, sur la situation en Centrafrique et à Madagascar et sur la Francophonie [En ligne]. URL: https://www.viepublique.fr/discours/190201-entretien-de-mme-yamina-benguigui-ministre-de-la-francophonie-avec-rfi 58 Extraits d'un entretien de Mme Yamina Benguigui, ministre de la francophonie, sur les relations franco-algériennes et sur la Francophonie, à Alger le 7 septembre 2012 [En ligne]. URL: https://www.vie-publique.fr/discours/185837-extraits-dun-entretien-de-mme-yamina-benguiguiministre-de-la-francoph

${ }^{59}$ Arrêté du 2 septembre 2015 portant nomination au cabinet de la ministre de travail, de l'emploi, de la formation professionnelle et du dialogue social // JORF. 30 septembre 2015. P. 17445.

60 Déclaration de Mme Yamina Benguigui, ministre de la francophonie, sur la Francophonie, à Paris le 29 août 2012 [En ligne]. URL: https://www.vie-publique.fr/discours/185780-declaration-de-mme-yaminabenguigui-ministre-de-la-francophonie-sur-la

${ }^{61}$ Déclaration de Mme Yamina Benguigui, ministre de la francophonie, sur la Francophonie, au Sénat le 10 février 2014 [En ligne]. URL: https://www.vie-publique.fr/discours/190436-declaration-de-mmeyamina-benguigui-ministre-de-la-francophonie-sur-la

62 Déclaration de Mme Yamina Benguigui, ministre de la francophonie, sur l'enseignement bilingue francophone, à Paris le 29 novembre 2012 [En ligne]. URL: https://www.vie-publique.fr/discours/186489declaration-de-mme-yamina-benguigui-ministre-de-la-francophonie-sur-l
} 
Інтереси Яміни Бенгігі брали гору над сферою її прямих повноважень, і паралельно з розробкою стратегії Франкофонії, вона періодично включалася у питання захисту прав жінок. Оскільки в уряді був окремий міністр із цих питань, у 2012-2014 рр. Наджат Валло Белькасем, потрібне було обгрунтування. Тому Я. Бенгігі апелювала до того, що «цінності Франкофонії включають у себе також і повагу до прав жінки»63. У липні 2012 р. під час поїздки до Демократичної республіки Конго для підготовки Саміту Франкофонії у Кіншасі до неї звернулася делегація жінок із прикордоння 3 Руандою, яка повідомила про звірства, від яких вони потерпають. Обурена Бенгігі апелювала до глави МЗС Лорана Фабіуса, і 30 липня Франція ініціювала позачергове засідання РБ ООН, а Франсуа Олланд анонсував скликання Світового форуму франкомовних жінок у Парижі, що й відбулося 20 березня 2013 р. Другий світовий форум франкомовних жінок відбувся у Кіншасі у березні 2014 р. напередодні припинення урядових повноважень Яміни. Перебуваючи у вересні 2013 р. з офіційним візитом у Нью Йорку, Яміна Бенгігі вкотре наголосила на проблемі ранніх шлюбів і статевого насильства, від якого потерпають дівчатка та жінки у різних куточках світу «під культурними, релігійними чи звичаєвими претекстами»64.

31 березня 2014 р. завершилася урядова кар'єра Яміни Бенгігі, яку, з огляду на махінації із незадекларованим майном у Бельгійському королівстві, не запросили в кабінет Мануеля Вальса, а на початку квітня 2014 р. усунули з мерії Парижу, куди вона внаслідок виборів повернулася напередодні. Попри судове розслідування, у листопаді 2014 р. Франсуа Олланд запросив Я. Бенгігі до складу французької делегації на XV саміт Франкофонії у Дакарі65. Судові справи тяглися до 2017 р., увінчалися умовним вироком, штрафом і тимчасовим позбавленням Ордену почесного легіону.

2014 рік зруйнував кар'єру Яміни Бенгігі, але вивів на велику політичну арену Міріем ель Хомрі, яка 26 серпня була призначена державним секретарем з питань політики міста. М.ель Хомрі народилася 1978 р. у Рабаті у сім'ї марокканського власника крамниці та бретонської вчительки англійської мови. У 1987 р. дівчинка з батьками переїхала до Франції, але зберегла подвійне громадянство. Розпочавши навчання на юридичному факультеті університету Бордо, 1999 р. поступила у престижний заклад Пантеон-I-Сорбона на політологію. Під час магістратури стажувалася у делегованому міністерстві з питань міста, що в серпні 2014 р. стане козирем при призначенні державним секретарем. У 2001-2002 рр. розпочала політичну кар'єру в мерії Парижа (як і Я. Бенґігі, під патронатом Бертрана Деланое) та вступила в Соціалістичну партію Франції. Її діяльність на цьому етапі була пов'язана із захистом прав чутливих категорій населення у неблагополучному XVIII окрузі Парижа, про що неодноразово згадуватиме під час урядової діяльності66.

\footnotetext{
${ }^{63}$ Déclaration de Mme Yamina Benguigui, ministre de la francophonie, sur la Francophonie, au Sénat le 10 février 2014 [En ligne]. URL: https://www.vie-publique.fr/discours/190436-declaration-de-mmeyamina-benguigui-ministre-de-la-francophonie-sur-la

64 Déclaration de Mme Yamina Benguigui, ministre de la francophonie, sur la lutte contre les mariages précoces et forcés, à New York le 25 septembre 2013 [En ligne]. URL: https://www.viepublique.fr/discours/189092-declaration-de-mme-yamina-benguigui-ministre-de-la-francophonie-sur-la 65 Yamina Benguigui, le choix du président // L'Opinion. 27 novembre 2014 [En ligne]. URL: https://www.lopinion.fr/edition/politique/yamina-benguigui-choix-president-18846

66 Déclaration de Mme Myriam El Khomri, secrétaire d'Etat à la politique de la ville, sur la politique de la ville notamemnt dans les quartiers, Nantes le 7 septembre 2014 [En ligne]. URL: https://www.viepublique.fr/discours/192194-declaration-de-mme-myriam-el-khomri-secretaire-detat-la-politique-de
} 
Міністр з питань праці, працевлаштування, професійного розвитку та соціального діалогу, яким М. ель Хомрі стала 2 вересня 2014 р., на відміну від державного секретаря, має право брати участь у всіх засіданнях уряду, а не лише тих, які безпосередньо стосуються його компетенції. Перше питання, над яким почала працювати ель Хомрі стосувалося вирішення проблем складних передмість. Постулюючи себе, як людину зі значним досвідом у цій сфері, Міріем апелювала до того, що жоден «план Маршала» у цих кварталах не принесе результату, якщо він реалізовуватиметься без залучення місцевих мешканців. А законними представниками їх інтересів є передусім локальні асоціації67. Вважаючи прості фінансові вливання безперспективними та марними, ель Хомрі пропонувала зосередитися на боротьбі проти дискримінації, радикалізації та створення умов для перекваліфікації населення шляхом освітніх ініціатив.

Для посилення цього блоку ініціатив восени 2014 р. міністерство призначило радника з питань громадянства та боротьби проти дискримінацій, яким став Мустафа Буджемаї. Як підкреслила М. ель Хомрі, «ми підняли боротьбу проти дискримінацій у ранг абсолютного пріоритету»68. У межах своїх повноважень Міріем зосередилася на дискримінації у трудовій сфері. Основними «підставами» до ксенофобії при працевлаштуванні міністр назвала вік особи, стать, інвалідність, фізичний вигляд, реальне або уявне походження, а також ім'я й адресу. Тому її відомство вперше 2016 р ініціювало анонімне тестування - надсилали на підприємства ідентичні за кваліфікаціями резюме, але використовували різні дискримінаційні «маркери»69. Після отриманих результатів працедавців-учасників заохочували до заходів-запобігань. Із 40 перевірених у першу хвилю підприємств лише два не запропонували план покращення. На думку міністра, «дискримінація - це не лише моральна помилка, а й економічний абсурд»70. Міріем ель Хомрі вважала, що якщо подолати дискримінацію у трудовій сфері за статевою ознакою та походженням, то за 15 років можна буде акумулювати додаткових 150 млрд. євро. Ель Хомрі визнавала, що попри всі докладені зусилля, бути жінкою у Франції означало мати нижчу зарплату (27\% жінок і 15\% чоловіків виконували некваліфіковану роботу), часткову зайнятість, виконувати всю домашню роботу (подвійне навантаження), нести левову частку обов'язків по догляду за дітьми ${ }^{71}$. У цьому ії погляди співпадали 3 Наджат Валло Белькасем, зауважимо, що дві політикині успішно координували свою діяльність.

\footnotetext{
67 Ibidem.

${ }^{68}$ Déclaration de Mme Myriam El Khomri, secrétaire d'Etat à la politique de la ville, sur la lutte pour l'égalité professionnelle et la diversité, Paris le 23 octobre 2014 [En ligne]. URL: https://www.viepublique.fr/discours/192706-declaration-de-mme-myriam-el-khomri-secretaire-detat-la-politique-de 69 Interview de Mme Myriam El Khomri, ministre du travail, de l'emploi, de la formation professionnelle et du dialogue social à France-Info le 18 avril 2016, sur les violences lors de l'occupation de la place de la République par «Nuit debout» et la lutte contre les discriminations à l'embauche [En ligne]. URL: https://www.vie-publique.fr/discours/198691-interview-de-mme-myriam-el-khomri-ministre-dutravail-de-lemploi-de

70 Déclaration de Mme Myriam El Khomri, ministre du travail, de l'emploi, de la formation professionnelle et du dialogue social, sur la lutte contre les discriminations à l'embauche et dans l'emploi selon les origines, Paris le 14 mars 2017 [En ligne]. URL: https://www.viepublique.fr/discours/202802-declaration-de-mme-myriam-el-khomri-ministre-du-travail-de-lemploi-d ${ }^{71}$ Déclaration de Mme Myriam El Khomri, ministre du travail, de l'emploi, de la formation professionnelle et du dialogue social, sur l'égalité professionnelle entre les hommes et les femmes, Paris le 31 mars 2016 [En ligne]. URL: https://www.vie-publique.fr/discours/199002-declaration-de-mmemyriam-el-khomri-ministre-du-travail-de-lemploi-d
} 
Важливою проблемою для Міріем ель Хомрі була боротьба проти релігійної дискримінації. Її надзвичайно обурило словосполучення «ісламо-фашизм», вжите главою уряду Мануелем Вальсом. Мадам ель Хомрі наголосила, що необхідно відокремлювати іслам та ідеологію такого кшталту, прикладом якої є ІДІЛ, яка «намагається поневолити жінок, використовує зґвалтування, як військову зброю»72. I, як не парадоксально, саме світськість має бути гарантом захисту та мирного розвитку ісламу в Республіці. Оскільки Франція зразка 2016 р. дуже відрізняється від Республіки 1905 р. Суспільство диверсифікувалося у контексті індивідуалізації способу життя, інтеграції численних міграційних хвиль. Найважливішим, на ії думку, було те, що $2 \frac{3}{3}$ французів не ідентифікували себе із жодною релігією, паралельно 3 цим, іслам в останні десятиліття показав величезний підйом, невід’ємний від колоніального минулого. Зустріч цих двох явищ - суспільної секуляризації та самоствердження ісламу вимагає уточнення політики, у тому числі й у трудовій сфері. Лаїцизм - це позитивний ідеал: «світськість дозволяє побудувати суспільство, яке нікого не дискримінує, ні мусульман, ні жінок. Світськість не протиставляє, не розділяє - вона об'єднує всіх» ${ }^{73}$. Забезпечуючи рівність представників різних конфесій та атеїстів, державний лаїцизм мусить втрутитися, якщо людина порушує інші принципи Республіки, зокрема, закриває обличчя у громадському місці, відмовляється потиснути руку представнику протилежної статі чи їсти за одним столом із колегою-іновірцем.

Не іслам, а ісламізм, як один із проявів радикалізації, ніс загрозу Республіці. Міріем ель Хомрі трактувала радикалізацію, як феномен маргіналізації, який стосується індивідів, що не хочуть брати участь у суспільному співжитті, роботі, освіті, асоціаціях тощо. Корені цієї проблеми в оточенні конкретної людини. I найбільш сприйнятлива для цієї агресивної ідеології молодь, тому її міністерство здійснила низку заходів, спрямовану на цю вікову категорію. У межах пріоритетних кварталів створили 700 посад соціальних працівників для «інтенсивного супроводу молоді», а також «школи другого шансу», тобто програми для осіб, які свого часу так i не отримали диплом про середню освіту ${ }^{74}$.

Але в історію Міріем ель Хомрі увійшла як авторка нової редакції Трудового кодексу 2016 р., яка спровокувала значне обурення у середовищі профспілок. Оскільки, «умови життя змінюються настільки швидко, що існуючий трудовий кодекс не може відповісти на всі виклики» ${ }^{75}$, одразу після очолення міністерства, зібрала авторитетних спеціалістів із трудового права, щоб спільно осмислити ймовірні шля-

\footnotetext{
72 Interview de Mme Myriam El Khomri, secrétaire d'Etat à la politique de la ville à LCI le 17 février 2015, sur la mixité sociale et la politique de la ville dans les quartiers [En ligne]. URL: https://www.viepublique.fr/discours/194085-interview-de-mme-myriam-el-khomri-secretaire-detat-la-politique-de-l

73 Déclaration de Mme Myriam El Khomri, ministre du travail, de l'emploi, de la formation professionnelle et du dialogue social, sur le fait religieux dans l'entreprise, Paris le 12 septembre 2016 [En ligne]. URL: https://www.vie-publique.fr/discours/200925-declaration-de-mme-myriam-el-khomriministre-du-travail-de-lemploi-d

74 Déclaration de Mme Myriam El Khomri, ministre du travail, de l'emploi, de la formation professionnelle et du dialogue social, sur la prévention de la radicalisation, Paris le 12 novembre 2015 [En ligne]. URL: https://www.vie-publique.fr/discours/198119-declaration-de-mme-myriam-el-khomriministre-du-travail-de-lemploi-d

75 Déclaration de Mme Myriam El Khomri, ministre du travail, de l'emploi, de la formation professionnelle et du dialogue social, sur la réforme du droit du travail et la réécriture du code du travail, Paris le 24 novembre 2015 [En ligne]. URL: https://www.vie-publique.fr/discours/197391-declarationde-mme-myriam-el-khomri-ministre-du-travail-de-lemploi-d
} 
хи реформ. Прикметно, що до процесу долучився навіть соратник Франсуа Міттерана, ініціатор скасування смертної кари та нового Кримінального кодексу 1992 р., Робер Бадінтер ${ }^{76}$. Міністр прагнула пристосувати трудове законодавство до умов все більш поширеного ненормованого робочого дня та віддаленої роботи. Однак, профспілки обурилися, насамперед, додатковими годинами, які можуть менше оплачуватися, аніж раніше, спрощеними процедурами звільнення та зміни трудових угод працедавцями ${ }^{77}$.

Попри те, що Міріем ель Хомрі опинилася між двох вогнів - як авторка трудової реформи й одночасно відповідальна за соціальний діалог, в інтерв'ю у вересні 2016 р. вона підтвердила, що переконана у правоті своїх дій і пишається цими законами ${ }^{78}$. Обурення маніфестантів посилював той факт, що Міріем ель Хомрі постійно наголошувала на своїй пов'язаності з XVIII округом Парижа, а тому мала б краще розуміти соціальну риторику. Але міністр усвідомила інше - ця реформа означала крах її загальнонаціональної політичної кар'єри, яка завершилася із поразкою Ф. Олланда на виборах навесні 2017 р. Як і Наджат Валло Белькасем («Саркозі дискредитований своєю діяльністю, і не може запропонувати нам ніякого уроку» ${ }^{79}$ ), так і Міріем ель Хомрі найбільше не хотіла, щоб новим Президентом став Ніколя Саркозі. Ель Хомрі навіть конкретизувала, що саме їй не подобалося у діяльності шостого Президента: «агресивне бачення Франції, визначені винуватці мусульмани, безробітні, функціонери, синдикалісти»80. I знову бачимо спробу боротьби проти ісламофобії.

Таким чином, проведене дослідження дозволяє зробити висновок, що підходи до залучення в уряд політиків-мусульман Ніколя Саркозі та Франсуа Олланда принципово відрізнялися. У той час, як для Н. Саркозі найважливішим було добсягти наглядної ілюстрації імплементації розробленого ним принципу «різноманіття», для Ф. Олланда концептуальною була саме злагодженість уряду. Тому троє 3 чотирьох політиків-мусульман (Наджат Валло Белькасем, Міріем ель Хомрі, Кадер Аріф) були членами пропрезидентської Соціалістичної партії, а формально безпар-

\footnotetext{
76 Interview de Mme Myriam El Khomri, ministre du travail, de l'emploi, de la formation professionnelle et du dialogue social à France-Inter le 26 janvier 2016, sur la réforme du code du travail, la question de la durée légale du travail et la négociation dans l'entreprise [En ligne]. URL: https://www.viepublique.fr/discours/197761-interview-de-mme-myriam-el-khomri-ministre-du-travail-de-lemploi-de 77 Interview de M. Jean-Marie Le Guen, secrétaire d'Etat aux relations avec le Parlement, à Europe 1 le 19 février 2016, sur le projet de loi El Khomri de réforme du Code du travail [En ligne]. URL: https://www.vie-publique.fr/discours/198054-interview-de-m-jean-marie-le-guen-secretaire-detataux-relations-avec

78 Interview de Mme Myriam El Khomri, ministre du travail, de l'emploi, de la formation professionnelle et du dialogue social à RTL le 16 septembre 2016, sur l'application de la loi sur la réforme du droit du travail et le dialogue social [En ligne]. URL: https://www.vie-publique.fr/discours/200926-interviewde-mme-myriam-el-khomri-ministre-du-travail-de-lemploi-de

${ }^{79}$ Interview de Mme Najat Vallaud-Belkacem, ministre de l'éducation nationale, de l'enseignement supérieur et de la recherche à Europe 1 le 25 août 2016 sur l'islam, le racisme et sur les arrêtés municipales anti burkinis [En ligne]. URL: https://www.vie-publique.fr/discours/200499-interview-de-mme-najatvallaud-belkacem-ministre-de-leducation-nationa

80 Interview de Mme Myriam El Khomri, ministre du travail, de l'emploi, de la formation professionnelle et du dialogue social à RTL le 16 septembre 2016, sur l'application de la loi sur la réforme du droit du travail et le dialogue social [En ligne]. URL: https://www.vie-publique.fr/discours/200926-interviewde-mme-myriam-el-khomri-ministre-du-travail-de-lemploi-de
} 
тійна Яміна Бенгігі тяжіла до лівих сил. I якщо Н.Саркозі намагався «посилити» «різноманітність» усіма можливими маркерами (особи ісламського віросповідання, жінки, представниці різних політичних сил), то Ф. Олланд відійшов від цього гендерного принципу (присутність в уряді К.Аріфа), керуючись насамперед професійними якостями.

Ф. Олланд повторив, започаткований Н. Саркозі, прецедент призначення мусульман повноправними міністрами, а не лише делегованими міністрами чи держсекретарями. I якщо у першому випадку йшлося про таке престижне відомство, як Міністерство юстиції, то в другому - ідеологічно важливе Міністерство національної освіти, вищої освіти та науки. У той же час у призначенні державним секретарем з питань ветеранів Кадера Аріфа видно паралелі із залученням Жаком Шираком на цю ж посаду Хамлауї Мекашера у 2002-2007 pр.

Троє з чотирьох політиків (К. Аріф, Н. Валло Белькасем і М. ель Хомрі) народилися не у Франції, при чому двоє (Н. Валло Белькасем і М. ель Хомрі) свідомо зберегли подвійне громадянство, що свідчить про важливість для них їхніх коренів. Тому у риториці вони апелювали до культурного, релігійного й етнічного різноманіття Республіки. А питання історії, політики пам'яті, світськості, боротьби проти усіх форм дискримінації були для них першочерговими.

Періодично роблячи спроби захистити ісламську культуру та мусульманську спільноту від закидів, тим не менше усі три політикині порушили одне з основних правил фікху - вийшли заміж за немусульманина: Наджат Валло Белькасем і Міріем ель Хомрі за християн, Яміна Бенгігі - за єврея алжирського походження. А якщо співставити цей факт із тим, що всі вони були активістками жіночого руху, виглядає, що таким чином намагалися взяти від Республіки максимум дивідендів, які б були неможливими у традиційному мусульманському суспільстві, паралельно апелюючи до необхідності захисту універсальних ісламських цінностей, постулюючи себе, як «світських мусульман», що для класичного ісламу апріорі неможливо.

\section{REFERENCES}

Aufray, S. (2014). Le site Mémoire des hommes et ses évolutions: entre mémoire et histoire [The site Mémoire des hommes and its evolutions: between memory and history]. La Gazette des archives, 236, 71-83; DOI: https://doi.org/10.3406/gazar.2014.5164 [in French].

Cardoso, A. (2014). La superwoman est-elle antiféministe? Analyse des discours de la presse féminine sur l'articulation entre vie professionnelle et vie familiale [The superwoman is she antiféministe? Discourse analysis of women's magazines on the relationship between work and family life]. Recherches féministes, 27 (1), 219-236. DOI: https://doi.org/10.7202/1025424ar [in French].

Collombet, C. (2016). Histoire des congés parentaux en France. Une lente sortie du modèle de rémunération de la mère au foyer [History of parental leave in France. A slow exit from the stay-athome mom pay model]. Revue des politiques sociales et familiales, 122, 111-122. DOI: https://doi.org/10.3406/caf.2016.3168 [in French].

Fleuri, B. (2008). Mémoires d'immigrés. L'heritage maghrébin de Yamina Benguigui. De l'ethos biographique aux hors sujets de la réception [Memories of immigrants. Yamina Benguigui's Maghrebian heritage. From the biographical ethos to subjects outside the reception]. Revuesanalyses, 3, Vol. 3, 99-121 [in French].

olland, F. (2019). Uroky vlady: memuary [Lessons of power: memoirs]. Kharkiv: «Folio» [in Ukrainian].

Sypko, B. (2016). Etno-sotsialni problemy frantsuzkykh peredmist na zlami XX-XXI st. [Ethno-social problems of French suburbs at the turn of the XX-XXI centuries]. In Wspołczesne wyzwania bezpieczeństwa Europejskiego (pp. 203-217). Kraków: Wydawnictwo Attyka [in Ukrainian].

Sypko, B. (2020). Musulmany v uriadakh Fransua Fiiona [Muslims in the Governments of François Fillon]. Eminak: Scientific Quarterly Journal, 2 (30), 209-219. DOI: https://doi.org/10.33782/eminak2020.2(30).421 [in Ukrainian].

Sypko, B. (2017). Musulmanska spilnota u zhytti Frantsuzkoi Respubliky (1995-2007) [Muslim 
Community in the Life of French Republic (1995-2007)]. Lviv: The Ivan Franko National University of Lviv [in Ukrainian].

Sypko, B. (2013). Ot «zabytykh istoriei» do subieektov obshchestvennykh otnoshenii: problema kharki v gody prezidentskoi kadentsii Zhaka Shiraka [From «forgotten by history» to subjects of social relations: the problem of the Harkis during the presidency of Jacques Chirac]. Społeczeństwo $i$ Polityka. Pismo edukacyjne, 3 (36), 229-239 [in Russian].

Sypko, B. (2017). Politychne zhyttia frantsuzkykh musulman: vid uchasti u vyborakh do uriadovykh posad (1995-2007) [Political life of French Muslims: from participation in elections to government posts (1995-2007)]. Visnyk of the Lviv University. Series History. Special Issue, 745-760. DOI: https://doi.org/10.30970/his.2017.0 [in Ukrainian].

Windisch, J. (2014). Omniprésence de l'image - omniprésence du président: Les caricatures sur Nicolas Sarkozy (2007-2012) [Omnipresence of the image - omnipresence of President: The cartoons on Nicolas Sarkozy (2007-2012)]. Wien: Universität Wien [in French].

\section{Bohdana Sypko}

(Ivan Franko Lviv National University, Lviv, Ukraine)

e-mail: bogdanasypko@gmail.com

ORCID: https://orcid.org/0000-0002-3136-9340

\section{Muslim Ministers in French Governments (2012-2017)}

At the beginning of the $21^{\text {st }}$ century, the French Republic was home to the largest Muslim community in the West, numbering 5-6 million people. E. Macron's initiatives aimed at defending the principle of secularism and combating 'Islamist separatism' provoked outrage in the Islamic world. The republic was blamed for systematic discrimination against Muslims and the lack of opportunities for self-realization of community members. Therefore, the analysis of the state of representation of Muslim politicians in the highest echelons of power is relevant.

The goal of the paper is to analyze the composition of French governments during the presidency of Francois Hollande and to trace the role played by Muslims in them, using a variety of sources (official state press, Senate and National Assembly reports, transcripts of speeches, interviews, and memoirs).

The concurrence of government was conceptual for F. Hollande. Therefore, three of the four Muslim politicians (Najat Vallaud-Belkacem, Myriam El Khomri, Kader Arif) were members of the pro-presidential Socialist Party. And formally non-party Yamina Benguigui gravitated to the Left. F. Hollande repeated, initiated by N.Sarkozy, the precedent of appointing Muslims as full-fledged ministers, not just delegated ministers or secretaries of state. If in the first case it was a matter of such a prestigious department as the Ministry of Justice, in the second it was about the ideologically important Ministry of National Education, Higher Education and Research. At the same time, the appointment of Kader Arif as Secretary of State for Veterans Affairs parallels with the appointment of Jacques Chirac to the same position in 2002-2007.

Three of the four politicians (K. Arif, N. Vallaud-Belkacem, and M. El Khomri) were not born in France. Two (N. Vallaud-Belkacem and M. El Khomri) retained dual citizenship. Therefore, in their rhetoric, they appealed to the cultural, religious and ethnic diversity of the Republic. And the issues of history, the politics of memory, secularism, the fight against all forms of discrimination were of top priority for them. Periodically trying to protect Islamic culture and the Muslim community from grievances, all three politicians violated one of the basic rules of fiqh, marrying a non-Muslim: Najat Vallaud-Belkacem and Myriam El Khomri married Christians, and Yamina Benguigui married the Jew of Algerian descent. And if to compare this with the fact that they all were activists of the women's movement, it looks like they tried to receive the maximum dividends from the Republic. That would be impossible in a traditional Muslim society. At the same time, they appealed to the need to protect universal 
Islamic values. And they postulated themselves as 'secular Muslims', which is a priori impossible for classical Islam.

Keywords: Islam, Muslim politicians, government, Francois Hollande, France 